\title{
War on Terra and Eco-Critical Discursivity: Analyzing the Role of Cultural Productions in Creating Eco-Consciousness
}

\author{
Umaira Aleem ${ }^{1}$, Inayat Ullah ${ }^{2}$, Aziz Ullah Khan ${ }^{1} \&$ Afzal Khan ${ }^{1}$ \\ ${ }^{1}$ Department of Humanities (English), Air University, Islamabad, Pakistan \\ ${ }^{2}$ English Language Center (ELC) at Deanship of Supportive Studies, Taif University, Taif, Saudi Arabia \\ Correspondence: Inayat Ullah, English Language Center (ELC) at Deanship of Supportive Studies, Taif \\ University, Taif, Kingdom of Saudi Arabia. E-mail: inayat_ktk@yahoo.com
}

Received: January 30, 2018 Accepted: February 20, 2018 Online Published: February 25, 2018

doi:10.5539/ijel.v8n3p339 URL: http://doi.org/10.5539/ijel.v8n3p339

\begin{abstract}
Euro-American exclusivity has been eclipsing the universalizing appeal of Ecocriticism, which attempts to counter the war on terra - the Latin name for earth. Ecocriticism also explores the connection between humans and their environment. It gives way to the examination of the environment and its illustration in literature and, by doing so, develops an investigative ecological consciousness regarding different environmental issues. The present study is aimed to study the non-Euro-American setting of Anis Shivani's Karachi Raj (2015) through an eco-critical lens. It attempts to explore the eco-critical consciousness of the characters, highlighting the way the effort of creating eco-consciousness is made through the settings and plot of the literary text. The study focuses on environmental issues presented in the novel through various situations. The research uses qualitative method of textual analysis under the theoretical underpinnings of Ecocriticism.
\end{abstract}

Keywords: eco-consciousness, Ecocriticism, Karachi Raj, Non-Euro-American literary texts

\section{Introduction}

The primary focus of Ecocriticism has been its universalizing appeal to counter the "war on Terra" (Note 1) by creating eco-consciousness among people. It is pertinent to mention here that nature and literature have a close and, quite often, celebrated relationship. With the advent of eco-consciousness as a universalizing point of discussion, Ecocriticism has become an increasingly growing field of literary studies. It binds literature with the environment and provides a reflection of the environment in literary texts. Notwithstanding the fact that Ecocriticism provides just one of the many different means of exploring literature, it, while doing so, construes various ecological and environmental issues in a literary piece of writing (Roy, 2014). It maintains that the man cannot afford having adverse relationship with the environment. As man is an integral part of the overall environmental system, called the ecosystem, in which man enjoys the status of the most important building block of the intricate system of the environment, he needs to bear in mind that he is neither a slave to, nor the master of, it (Klue, 2008). According to Soper (2009), Ecocriticism is an ecological extension of post-structural criticism that studies human representations of nature.

\section{Literature Review}

\subsection{Ecocriticism and Critique of Literary Texts}

Before embarking upon analyzing and discussing the related literary text with reference to the available scholarship on Ecocriticism, it is apt to overview the studies accomplished in this field. The institutional formation of Ecocriticism has been dealt through different perspectives (Cohen, 2004; Garrard, 2012; Glotfelty, 1996; Love, 2003; Branch \& Slovic, 2008). Diverse projects and publications contributed to the foundation of Association for the Study of Literature and Environment (ASLE), during Western Literature Association convention in 1992. The journal titled Interdisciplinary Studies in Literature and Environment (ISLE) was established in 1993 while, in 1995, the Association for the Study of Literature and Environment started conducting periodic conferences (Heise, 2006). Other than this, some influential texts and collections, such as The Environmental Imagination (Buell, 1995) and What is Nature? Culture, Politics and Non-Human (Soper, 2009) made a considerable contribution to the field of ecocriticism. Today, the newly emerging works in ecocriticism have begun to connect the dots of the intellectual concerns to the pivotal works in American and 
British literary studies, such as Virgin Land (Smith, 1950), Marx's the Machine in the Garden (2000), Roderick's Wilderness and the American Mind (1967), Raymond's The Country and the City (1973), and many more.

Buel (2005) differentiates among the three stages of eco-criticism and terms them as the waves of Ecocriticism. According to him, eco-criticism has evolved from the first wave to the second, and now the third wave of eco-criticism is in the vogue.

The first wave of eco-criticism, preferably, focused on the natural environment. At the initial level, the function of an eco-critic was taken as the caretaker of the earth. Enger \& Smith (2004) define the environment as a set of the surrounding conditions, which affect the human beings and, in turn, are affected themselves too. These effects can be in terms of health, politics, ethics, economics and society.

On the other hand, the second wave of Ecocriticism dealt with life sciences. It emphasized that biological thinking, Ecocriticism and the study of literature and environment are interlinked. Slovic (2010) highlights the third wave of eco- criticism, which emerged in 2000 and is continued enthusiastically, at present. The third wave deals with the new trends and issues that the world is facing today, including the global concept of place and dis-locality, global soul and trans-locality.

Barry (2002) describes the ways eco-critics deal with any literary text. According to him, eco-critics focus on the representation of the natural world and inspect literary texts through an eco-critical lens, and extend the domain of Ecocriticism by including themes of balance and imbalance, growth and energy, and symbiosis and mutuality. Eco-critics celebrate writers, who weave and foreground nature as a subject matter of their work.

\subsection{Non-Euro-American Literary Texts and Eco-consciousness}

The development of environmental literary criticism and the latest debates going on, in this field, show as if the protection of the environment, with an ecological consciousness, has been limited to the status of an elitist concern of the first world countries. The increasingly Euro-American presence in the environmental literary scholarship, as well as the critique thereof, goes on to show as if the developing, read non-Euro-American, countries pay no attention to the natural surroundings they live in, and as if their sole concern is the consumption of the available resources. In the same vein, the literary critical milieu of environmental studies has not been paying much attention to the literature, produced in the developing countries.

In this context, the present study seeks to fill the gap in the related critical literature by exploring how environment has been portrayed by one of the prominent authors of Pakistani Anglophone literature in the form of Karachi Raj. The major question this study raises is whether Shivani's text culminates into highlighting the environmental concerns. The other research question takes this concern further and explores what factors are responsible for either the marginalization or celebration of environment in the selected literary text. The notions of ecological consciousness and eco-centrism form the theoretical framework for this study.

Karachi Raj unfolds a multi-layered story of the inhabitants of Karachi. Through an invisible contrast, the writer juxtaposes the microcosm that exists in the form of Basti (Urdu word for slums) and metropolitan Karachi. The characters in the novel are as diverse as Karachi itself in terms of ethnicity, race, culture, social status and language. Some of them breathe life and make larger-than-life personae in their own dispositions. The story revolves around Hafiz and Seema, two siblings, living in the basti-the Orangi Pilot Project (OPP), along with their parents.

The novel gives life to the sophisticated and very special relationship between the two siblings. They grow up into well-matured and sensible beings, despite the trials that life had thrown to them. Even in the terror prone city, all they manage to see around themselves is love and goodness. They belong to a poor family, and their parents work in a garment factory. Hafiz also strives for earning as a salesman at a go-down, and then at Haji Suleman's shop. Only Seema is the one in the family who is privileged not to work as she studies in Karachi University and is a student of Mr. Ashiq, a professor in the History department. Seema seeks refuge from the deprivations and harsh realities of life by visiting Ashiq frequently. Seema's fascination and awe for the much older, literati of Karachi University History Professor Ashiq, whose intensity of his good looks had only grown after he turned 40, and who, she is grateful of offering her a window into another world and saved her from the hell of anonymity of the basti and Hafiz's infatuation for his colleague's wife who betrayed him and left him in trail and tribulation of searching of a new job make the substance of the story. Claire, the anthropology professor from Boston University, has come to the basti to explore the reason of its existence there.

Claire is taken as a daring person even by her local co-workers at the basti office, who wonder and cannot understand why a white, blonde woman, who also starts wearing headscarf, would readily offer herself to the wanton misery. She speaks the language of the people of the basti, hopes to dream in it. Other than these 
characters, Shivani introduces Helga and Molly, two foreigners working with Claire in the basti, Karim, Abdullah, Qudsia, Karim's sister, a window inside the basti and its activities. Ashiq's elite sisters, his brother in laws and his parents make another world full of resources and contentment having dreams bigger than the bread.

Hafiz, after many diversions at the workplace, finally ends up again working for Majid, this time as personal assistant to his beautiful actor wife, Hina. The various career paths affects Hafiz and he changes like a chameleon symbolizing the city itself -to survive. On the other hand Seema's infatuation with Professor Ashiq ends up as the professor gets cold feet. Seema takes journalism as profession and joins an English newspaper as reporter. Ashiq remains a confirmed and confused bachelor till the end of the novel.

The novel shows Karachi developing with the improvement of many issues and problems. There are no heavy scenes as the novel ends smoothly. Only a heavy flood at the end leaves basti and its drainage system helpless, highlighting the environmental issues at a number of such slums. Shivani decides on how he wished to have a reunion with Karachi that was, once, not that dirty. He anticipated the book to be a counter narrative to the journalistic myths and conventional notions about Pakistan. He maintains that he had unequivocally decided to write a funny, light hearted, fast-paced book, a book of optimism and energy, even though it took into account the dark side of Pakistani life (Ahmed, 2015).

The paper aims at exploring the darker sides of the environmental situation the city and suburbs of Karachi. The novel has been seen through an eco-critical lens and this investigation brings into focus many issues, which most of the characters expressed, and were equally affected by, in the novel.

\section{Research Methodology}

Qualitative method of research, also known as a non-mathematical investigative practice, is used to find results in the research. The idea that qualitative research, unlike quantitative method of analysis, goes beyond the hard data, (Grahame, 1999; Silverman, 2001) has been applied on the selected literary text. Mostly researchers in the field of social and behavioral sciences prefer the employment of qualitative research method. This approach of analysis is also utilized by the specialists dealing with issues of human behavior and functioning. Researchers believe that qualitative research actually provides an in-depth and detailed understanding of social phenomena which otherwise is difficult to attain from quantitative data analysis tools. In the present study, the conceptual tool of Eco-criticism has been employed to seek answers of the questions and it is helpful to read the literary texts through the eco-lens.

\section{Analysis and Discussion}

\subsection{Elements of Eco-consciousness in Karachi Raj}

The eco-critical study of the novel Karachi Raj explores the text and its characters in different interesting dimensions, all of which are related to the issue of environmental nature. The textual analysis under the ecological consciousness lens has brought to surface these issues: As an ethnic and sectarian city, Karachi caters for all sects in its environment. The doubts and questioning of Bibi, when the hospital wanted her bio data as a visitor, suggest that religion in all form is not harmonious for the inhabitants of Karachi: "Today a nurse was asking me to fill out a questionnaire, including my religious and political beliefs. I'm not some Ismaili or Qadiani, so why are they after me?" (p. 36).

In universities and institutions in Pakistan, religion is not a topic of free discussion. The writer foregrounds the allegation of blasphemy, common in our society: "Professor Ashiq Rasool, facing charges of blasphemy from disgruntled Jama'atis who have gathered solid evidence... (p. 137). The heated arguments of students with the professor shows the difference between the culture and academics, how a wide gap has created misconception: "History teaches us the same lessons Islam does. There's no separation between the two, none whatsoever" (p. 138). The sensitive issue of sectarianism has been portrayed with full intensity through Shia Sunni conflict and their intolerance for each other. When a bomb exploded at the Ashura procession and killed hundreds of mourners and the Arabian horse, the city saw the retaliation in basti: "Thousands of shops belonging to Sunnis were burnt... The shops belonged to the same traders who built sabeels, water stations, for the thirsty marchers in the Shia procession" (p. 159). The visitors to Haji Suleman's book store poses serious questions to the dilemma of Islamic scholars who are unable to resolve sectarian as well as political crisis in the country: "Arrey bhai, just because Imam Ghazali said certain things about women doesn't mean we have to follow his every word. In Islam, the principle of ijtihad applies. Independent thinking... Can any science shut its doors? Who has the keys anyway?" (p. 102). "We don't care who rules the country. It only distracts from accumulating blessings" (p. 102). While the elite class has a different religious views, Rauf, Rehana's husband gives vent to the politics and religion both: "Does Allah, the master of the universe, have the free time to bother with my little decision? 
That's a mockery of Allah, a puppet we've set up for our pleasure... The trouble started with Zia. He used Islam to corrupt us." (p. 116).

"Karachi has eighteen million people. Each neighborhood is sufficient unto itself, so you need not stray far from where you live." The elopement of daughter makes Haji Ibrahim to describe Karachi as a hide out for all doing wrongs: "She's in Karachi as we speak-Allah knows where, in whose house, under what conditions, but my heart tells me she's in this city. Even al-Qaeda hides in this city, Osama bin Laden is probably in this city." (p. 130)

"Today people sit in front of sparkling lights all day. The computer. The television. I'm telling you, it's depressing here" (p. 132). Imagine, many dukanwallahs are relying on computers! I don't see the need of computers in a house of religion..." (p. 100). The issues regarding hygiene are described through different situations in the novel. The personal hygiene appears as a not-to-be-neglected concern with the entry of Haji Ibrahim, the brother of Haji Suleman, from Lahore in the shop and life of Haji Suleman and Hafiz who as typical Karachities never bother about potential threats of eating together and sharing utensils together: "Bhai Suleiman, don't you worry about germs? It's uncouth to eat like tablighis" (p. 133). The sanitation in basti is something unbelievable for the inhabitants living in the paved and planned housing societies: "What's it like living in the basti? Don't you get ill? Do you take special pills? What about the stench? And the dust?" (p. 157).

The concept of space is dealt differently in the environment of the novel. The elite class secludes their homes from the country in which they are situated: "Not in this house, you won't find a speck of dust". On the other side: "Imagine living in Pakistan and being allergic to dust!" (p. 157). Karachi's diversity and multidimensional identity is relatable with complexity of life there, the foreigners for Haji Ibrahim are dwellers for people living in Karachi: "Tibetans, Uzbeks, Mongols, Bangalis, Yemenis, Ethiopians, Burmeses, Chinese, Arabs and of course Pathans of every kind-always Pathans and Afghans, with their karakuli caps and foul smelling niswar and street tandoors and guns. There are more Pathans here than in Peshawar. There are more Baluchis here than in Quetta". "In Lahore, everyone looks like a Punjabi, but what is the Karachi look? You can't tell me because there isn't one" (p. 167).

Basti portrays the place devoid of security and protection: "A police chase was on. Someone was shouting after someone else for only daughter's dowry". Basti offers itself as a safe haven for the criminals of the city: "Reward one lakh rupees. Famous criminal Allah Bakhsh alias Dada has been reported in the vicinity... Criminal Allah Bakhsh alias Dada is on the run. Reward one lakh rupees" (p. 126).

The development in the city shows the level of seriousness and professionalism of the concerned: "Flyovers they're building all over the city, like madmen, as if this were Peking or New Delhi, but what about the poor pedestrian?" (p. 99). Whereas basti with the poor condition remains protected from the perks of development in the city: "Entering the basti, the familiar smell-evoking sawdust and varnish and ducks marooned in stagnant water... The quiet of the basti was dreamlike; without traffic, pollution, noise, construction and speed, it felt like going back in time" (p. 178). But basti is not a unit of good and planned infrastructure: "They were driving along the main road...Everything looked dirtier, smaller, more haphazard" (p. 174).

The presence and absence of noise pollution as an unattended environmental has been incorporated at backdrop of many situations in the novel: "They say the phutter of the rickshaw keeps the patients awake at night. Bhai, if you have a broken leg and arm, as everyone in this ward does, the rickshaw is least of your worries" (p. 69).

Overall novel portrays life in city and basti at risk of life. City faces crowd, traffic jams, and unavailability of parking place: "One of the great pleasures of Karachi is to park on the road like this and allow yourself to be oblivious to other people" (p. 107). While basti has to face atrocities of city life in terms of loss of life and accidents, Allah Ditti one old lady from basti tells her story of loss: "My first husband was run over by a municipal bus, a big red one... We had two sons. One died of tuberculosis..." (p. 56).

\section{Conclusion and Recommendations}

Karachi Raj is an ecological conscious novel that highlights several issues, faced by the people of a metropolitan city and its small "unauthorized city within the city," (p. 5) called basti. The pollution, including water pollution, air pollution, noise pollution, the mismanagement at every level whether government sector or public and the resultant social evils of bribery, corruption, poverty and crimes, have been dealt with by the novelist in an appropriate manner. The unequal distribution of resources, including wealth, education, and health facilities; the misconceptions about the use of new technologies and doubts about the scientific findings; and ignorance, illiteracy, rigidity, sectarianism are the elements through which nature has been portrayed in the novel. The writer depicts nature in terms of deterioration of environment and exploitation as well as mismanagement of natural resources. The analysis of the novel through an eco-critical lens establishes the fact that people of the 
third world countries, despite living in a developed and cosmopolitan city are unaware of ecological loss they are doing to their environment.

\section{References}

Ahmed, A. (2015). Book review: Karachi Raj | Newsline [Web log post]. Retrieved from http://newslinemagazine.com/magazine/book-review-karachi-raj/

Barry, P. (2002). Ecocriticism. Beginning theory: An introduction to literary and cultural theory (p. 264). Manchester, UK: Manchester University Press.

Branch, M. P., \& Slovic, S. (2008). The ISLE reader: Ecocriticism, 1993-2003. Athens, Ga. [u.a.: Univ. of Georgia Press.

Buell, L. (1995). The Environmental Imagination: Thoreau, Nature Writing, and the Formation of American Culture. The Journal of American History, 82(3), 12-15. https://doi.org/10.2307/2945179

Buell, L. (2005). The Future of Environmental Criticism: Environmental Crisis and Literary Imagination. Oxford: Blackwell Publishing Ltd.

Cohen, M. P. (2004). Blues in the Green: Ecocriticism under Critique. Environmental History, 9(1), 9-14. https://doi.org/10.2307/3985943

Enger, E. D., \& Smith, B. F. (2004). Environmental Science: A Study of Interrelationship. New York: McGRAW-Hill.

Garrard, G. (2012). Introduction. Teaching ecocriticism and green cultural studies (pp. 3-15). Houndmills, Basingstoke: Palgrave Macmillan. https://doi.org/10.1057/9780230358393

Garrard, G. (2014). Ecocriticism. Place of publication not identified. London, New York: Routledge. https://doi.org/10.1093/oxfordhb/9780199742929.013.032

Glotfelty, C. (1996). Ecocriticism: literary studies in an age of environmental crisis. Interconnections Between Human and Ecosystem Health, 229-236. https://doi.org/10.1007/978-94-009-1523-7_15

Heise, U. K. (2006). The Hitchhiker's Guide to Ecocriticism. The Modern Language Association of America, 12(2), 505.

Khan, N. (2014). Ecocriticism. A New Response to Indian Poetry from Tagore to Present: Eco-poetry. Retrieved from https://www.grin.com/document/283816

Klue, C. A. (2008). Man's Return to Nature. Athens: University of Georgia Press.

Lawrence, B. (1995). The Environmental Imagination: Thoreau, Nature Writing, and the Formation of American Culture. Isis, 88(3), 554-555.

Love, G. A. (2003). Practical ecocriticism: Literature, biology, and the environment. Charlottesville: University of Virginia Press.

Marx, L. (2000). The machine in the garden: Technology and the pastoral ideal in America. New York: Oxford University Press.

Raymond, W. (1973). The Country and the City. New York: Oxford.

Roderick, N. (1967). Wilderness and the American Mind. New Haven: Yale.

Roy, A. (2014). Green Poems: An Ecocritical Reading of Select Indian Poems in English. MIT International Journal of English Language \& Literature, 1(2), 92-99. Retrieved from https://www.google.com.pk/url?sa=t\&rct=j\&q=\&esrc=s\&source=web\&cd=1\&cad=rja\&uact=8\&ved=0ahU

Shivani, A. (2015). August. In Karachi raj (p. 36). New Delhi, IN: FOURTH ESTATE.

Slovic, S. (2010). The Third Wave of Ecocriticism: North American Reflections on the Current Phase of the Discipline. Ecozon, $\quad l(1), \quad 4-8 . \quad$ Retrieved from https://www.google.com.pk/url?sa $=\mathrm{t} \& \mathrm{rct}=\mathrm{j} \& \mathrm{q}=\& \mathrm{esrc}=\mathrm{s} \&$ source=web $\& \mathrm{~cd}=2 \& \mathrm{cad}=\mathrm{rja} \&$ uact $=8 \& \mathrm{ved}=0 \mathrm{ahU}$ KEwie09GKtY7YAhVRKuwKHRdyCUAQFggvMAE\&url=https\%3A\%2F\%2Fdspace.uah.es\%2Fdspace\% 2Fhandle\%2F10017\%2F21206\&usg=AOvVaw2iCeezpUh4B61RbpWfYd2J

Smith, H. N. (1950). Virgin land: The American West as symbol and myth. Harvard UP: Cambridge.

Soper, K. (2009). What is nature?: Culture, politics and the non-human/ Kate Soper. Oxford [u.a.: Blackwell.

Teague, D. (1997). The Ecocriticism Reader: Landmarks in Literary Ecology. In C. Glotfelty \& H. Fromm (Eds.), 
Western American Literature, 31(4), 401-402. https://doi.org/10.1353/wal.1997.0009

Tiiu Speek, T. (n. d.). LAWRENCE BUELL's ECOCRITOCAL PERSPECTIVE. ENVIRONMENT IN LITERATURE.

Retrieved

from

https://www.google.com.pk/url?sa=t\&rct=j\&q=\&esrc=s\&source=web\&cd=1\&cad=rja\&uact=8\&ved=0ahU

KEwiv-9GD8I3YAhUO_qQKHXruBd0QFggmMAA\&url=http\%3A\%2F\%2Fwww.eki.ee\%2Fkm\%2Fplace \%2Fpdf\%2FKP1_18speek.pdf\&usg=AOvVaw38b-KcX2TeI7VZ86DizwVX

\section{Note}

Note 1. The expression "war on Terra" was used by Professor Dr Muhammad Safeer Awan during his keynote speech at the National conference on Contemporary Trends in English Language and Literature (CTELL), held at Allama Iqbal Open University (AIOU), Islamabad, Pakistan, on 13-14 October 2017. The word Terra is the Latin name for earth.

\section{Copyrights}

Copyright for this article is retained by the author(s), with first publication rights granted to the journal.

This is an open-access article distributed under the terms and conditions of the Creative Commons Attribution license (http://creativecommons.org/licenses/by/4.0/). 